\title{
Suriyeli Mültecilerin Mekânsal Analizi: Şanlıurfa Örneği
}

\section{Spatial Analysis of Syrian Refugees: The Şanluurfa Case}

\author{
Diyar KARADEMİR ${ }^{1} \oplus$, Mesut DOĞAN ${ }^{2} \odot$
}

${ }^{1}$ Şanlıurfa Spor Lisesi, Şanlıurfa, Türkiye

${ }^{2}$ İstanbul Üniversitesi, Edebiyat Fakültesi Coğrafya Bölümü, İstanbul,Tükiye

ORCID: D.K. 0000-0002-9991-3867; M.D. 0000-0002-4926-5769

\section{öz}

Göç olgusu, coğrafi olarak iki mekân arasında yer değiştirmenin yanı sıra toplumsal değişim ve dönüşüm üzerinde önemli etkiye sahiptir. Suriye'de 2011 yılında ortaya çıkan iç karışıklıklar zamanla bir iç savaşa dönüşmüştür. Suriye ile sınır komşusu olan ülkeler arasında savaştan en çok etkilenen ülkelerin başında Türkiye gelmektedir. Ülkemizin benimsediği “Açık Kapı” politikası nedeniyle başta Suriye sınırında yer alan illerimizde olmak üzere Suriyeli mülteci sayısı hızla artmıştır. Şanlıurfa i̇li bu durumdan en fazla etkilenen illerin başında gelmektedir. Bu çalışma Güneydoğu Anadolu Bölgesi Orta Fırat Bölümü'nde yer alan büyük bir kısmı plato sahalarından oluşan Şanlıurfa İlini kapsamaktadır. Suriyeli mültecilerle ilgili Şanlıurfa II Milli Eğitim Müdürlüğü PiCTES Biriminden alınan farklı yaş gruplarında okula devam eden öğrenci sayılarından ve Göç İdaresi Genel Müdürlüğü’nün yayınladığı bültenler ışığında Şanlıurfa ìlinde kamp dışında kalan Suriyeli sığınmacıların ilçeler bazında dağılış analizleri yapılmıştır. Dağılışın fazla olduğu sahalarla sosyo-ekonomik yapı arasındaki bağlantı incelenmiştir. Çalışmada durum tespiti yapmak amacıyla 20 Suriyeli aileyle derinlemesine görüşme tekniği uygulanmıştır. Önceden katılımcılar için sorular hazırlanmış ancak konuşmanın seyrine göre katılımcılara yeni sorularda sorulmuştur. Elde edilen verilerin özgün içeriklerine sadık kalınmış ve söylenilenlerden alıntılar yapılarak analizler yapılmıştır.

Anahtar kelimeler: Şanlıurfa, Göç, Suriyeli Mülteciler

\section{ABSTRACT}

Even though the phenomenon of migration is moving from one geographical location to another, it has a significant impact on societal change and transformation. The internal unrest in Syria which began in 2011 has escalated into a civil war in the course of time. Turkey, among other bordering countries with Syria, is the one which is affected most by the war. Due to the "Open Door Policy" adopted by our country, the number of Syrian refugees has soared in Turkey, especially in our provinces on the Syrian border. Şanlıurfa is one of these provinces affected most by this situation. This study covers the Şanlıurfa Province located in the Middle Euphrates Region in Southeastern Anatolia, a large part of which is composed of plateaus. The relationship between the areas where the distribution is intense and the socioeconomical structure was examined. In order to understand the situation, in-depth interviews were made with 20 Syrian families. The questions were prepared for participants in advance, but additional questions were also asked in the course of interviews. Unique contents of the obtained data were adhered to, and the analyses were made based on the citations from the statements of participants.

Keywords: Migration, Şanlıurfa, Syrian Refugees 


\section{EXTENDED ABSTRACT}

Qualitative and quantitative research techniques were employed in the study. Quantitative data: In the light of the bulletins published by Directorate General of Migration Management and based on the data regarding the students in various age groups who attended schools in 2018- 2019 academic year in Şanlıurfa province by districts and schools obtained from PICTES Department of Şanlıurfa Provincial Directorate for National Education, the neighborhoods where the schools are located were determined and distribution maps for the districts and neighborhoods were prepared. Qualitative techniques: In-depth interviews and participant observation techniques were used with 20 Syrian families to determine the situation of Syrian refugees. The questions were prepared for participants in advance, but additional questions were also asked in the course of interviews. Unique contents of the obtained data were adhered to, and the analyses were made based on the citations from the statements of participants. In order to obtain more realistic results from the study, snowball sampling or the chain sampling technique was used in neighborhoods where spatial clustering was intense.

Şanliurfa is one of the provinces affected most by the civil war in Syria. Determination of the number of Syrian students attending schools in various age groups, determination of the spatial clustering of Syrian refugees in the Şanliurfa province, determination of the relationship between the spaces where distribution is intense and socio-economical structure, being able to make integration plans by age groups, and socio-economical, cultural and spatial influences of Syrian refugees on the city are the factors that make this study significant.

Obtaining important results at the end of the face-to-face interviews made with Syrian refugees regarding their status before migration, migration processes, their nutrition and sheltering, their belonging, relationships with local community and repatriation after the war are other factors which make this study important.

The distribution of Syrian students in the Şanlıurfa province by districts and neighborhoods helped us gain insight about the distribution of Syrian refugees in the province. Accordingly, it was observed that the refugees prefer to settle in the Akçakale, Ceylanpınar and Suruç districts as they are located on the border, and in the Haliliye and Eyyübiye districts as there are more employment opportunities, possibilities and a chance to have an urban life-style in these districts. The number of Syrian refugees in the Birecik and Viranşehir districts is higher than that of the Bozova, Halfeti, Hilvan and Siverek districts because they are located on the historical Silk Road. Bozova, Hilvan and Halfeti are socio-economically underdeveloped districts and consequently, the distribution of Syrian refugees in these districts is not high.

The distribution of Syrian refugees by neighborhoods is shaped depending on the socio-economical structure. While the distribution in rural neighborhoods is low, the areas in the cities where there are central working areas and where the home rental prices are low are preferred. In the Haliliye and Eyyübiye districts where the distribution of refugees is high, the highest distribution of refugees is observed in Devteşti, Bağlarbaşı, Süleymaniye, Ahmet Yesevi, Cengiz Topel, Bamyasuyu, Şehitlik, Yeşil Direk, İmam Bakır, Şair Nabi, Sancaktar, Hayatı Harrani, Eyüpkent, Direkli, Akşemsettin, Eyyüpnebi, Muradiye, Akabe, Topdağı, Haleplibahçe, Kurtuluş, Onikiler and Hakimdede neighborhoods. Some of these neighborhoods constitute the core of Şanlıurfa province, but squatting is rather high in some others as a result of migration from rural areas and people from low income groups are settled in them. For this reason, the Syrians who have economic difficulties are mostly distributed in these neighborhoods.

Even though the consequences of businesses started by Syrians in business centers are positive in terms of supply and demand in Şanliurfa, as in many other provinces, the local community shows individual and mass reactions to Syrians as they are regarded as low-cost labor and the number of unemployed persons in the province has increased. Even though social and spatial clusters formed by Syrian refugees have positive consequences in terms of having their own identity and culture, this seems to create problems in respect to their sense of belonging and social cohesion. As a matter of fact, it is observed that neighbor relations are weakened and exclusion has increased after 2017. Furthermore, the provision of healthcare and education services to Syrian refugees for free sets off reactions among the local community. 
One of the issues that makes it difficult for female Syrian refugees to fit into society is the perspective of the local community on female children or women. Seeing Syrian women as a purchasable and sellable commodity, having them as second wives, getting them to marry with old persons for money make it difficult for female refugees to fit into the community.

As a consequence, Syrian refugees have become one of the most important problems for our country. Although the local community exhibits some exclusionary behaviors against the Syrians, the majority of the participants are not considering going back to Syria for security reasons. 


\section{GÍRIŞ}

Göç, kalıcı veya yarı kalıcı olarak yapılan ikamet değişikliği (Lee, 1966: 49), kısaca insanların bir yerden başka bir hareket etmesi sonucu meydana gelen mekân değişikliği sürecidir. İnsanlık tarihinin ortak bir olgusu olan göç, geçmişi binlerce yıl öncesine dayanan coğrafi bir olgudur (Bartram vd., 2017:13). Göç, idari bir sınırın geçilmesiyle beraber oturma yerinin devamlı veya uzun süreli olarak coğrafi olarak yer değiştirme hareketidir (Karpat, 2013; Keleş, 1998; Tümertekin \& Özgüç, 2002: 308). Bu değişim uluslararası, bölgelerarası, kırdan şehre veya şehirden kıra doğru belirli bir yönde meydana gelebilir (Tümertekin \& Özgüç, 2002: 308). İlk göçler, coğrafi şartlarla beraber yiyecek bulma ihtiyacından meydana gelmiştir (Tanoğlu, 1969: 84). Tarihi süreçler boyunca nüfus dalgalanmalarında en önemli etkiyi göçler oluşturmuştur (Sertkaya Doğan, 2009: 6). Mekân değiştirme süreci sonucunda toplum yapısı ekonomik, sosyal, kültürel ve siyasi olarak çeşitli değişimler geçirmesi göç hareketinin sonucudur (Özer, 2004; Zapata-Barrero ve Yalaz, 2018: 1). Yer değiştirme eyleminin bitmesiyle göç olgusunun etkileri sosyolojik olarak devam eder (Çakır, 2011: 131; Harunoğulları, 2016: 373).

Uluslararası göç, küreselleşmeyle birlikte devletler tarafından daha çok ciddiye alınmaya başlanmış (Castles vd., 2014: 5) ayrıca göç olgusu çok sayıda disipline konu olduğundan birbiriyle bağlantılı veya bağlantısız göçle ilgili çeşitli göç kuramları ortaya atılmıştır (Massey vd., 1993: 12). Everest Lee'nin (1966) İtme-çekme Teorisi, Ravenstein'in (1885) Göç Kanunları, Yeni Ekonomi: Makro Kuram, Kesişen Fırsatlar, Marksist ve A $\breve{g}$ (Network) Teorileri örnek verilebilir. Uluslararası göçle beraber ortaya çıkan sorunlar, devletler hukukunda çeşitli kavramların ve yasal hakların ortaya çıkmasını beraberinde getirmiştir. Mülteci, sığınmacı, göçmen, yasadışı göçmen, iltica vb.

BM Mülteciler Yüksek Komiserliği’nin (UNHCR) verilerine göre 2018 yılı sonu itibariyle dünyada 70.8 milyon zorla yerinden edilmiş insan, 25.9 milyon mülteci, 41.3 milyon kendi ülkeleri içinde yerinden edilmiş kişi ve 3.5 milyon sığınmacı bulunmaktadır. Ülkemiz coğrafi konumu itibariyle dünyadaki önemli petrol sahalarını oluşturan Ortadoğu ve Arabistan Yarımadasına yakınlığı, Asya ve Avrupa arasında geçiş güzergâhında yer alması ve üç tarafının denizlerle çevrili olması nedeniyle uluslararası göçün transit ülkelerinden biridir. Emperyalist ülkelerin müdahaleleri sonucu Ortadoğu'da birçok ülkede siyasi istikrarsızlık veya iç karışıklıklar ortaya çıkmaktadır. Bu durum gelişmiş Avrupa ülkelerine göç etmek isteyen on binlerce mültecinin ülkemizi geçiş bölgesi olarak kullanmasına neden olmuştur.

2011 yılı Mart ayında Suriye'de başlayan iç karışıklıklar büyüyerek bir iç savaşa dönüşmüştür. Suriye'deki iç savaş nedeniyle milyonlarca insan yerinden olmuştur. Suriye ile sınır komşusu olması nedeniyle ülkemiz Suriye'deki iç savaştan en fazla etkilenen ülke olmuştur. Kitlesel olarak gerçekleşen göçler sonucunda 3.6 milyon Suriyeli mülteci ülkemize göç etmiștir (UNHCR, 2019). Mülteci göçlerinden sınırda yer alan illerimiz (Gaziantep, Hatay, Şanlıurfa, Kilis vb.) başta olmak üzere iş imkanları bulunan büyükşehirler (İstanbul, Ankara, İzmir, Bursa vb.) sosyal ve ekonomik bakımdan etkilenmiştir.

\section{VERİ YÖNTEM}

Çalışma temelini nitel ve nicel araştırma teknikleri oluşturmaktadır. Nicel veri; Göç İdaresi Genel Müdürlüğü’nün yayınladığı bültenler ışığında ve Şanlıurfa İl Milli Eğitim Müdürlüğü PİCTES biriminden 2018-2019 eğitim öğretim yılında Şanlıurfa ilinde eğitim gören farklı yaş gruplarında okula devam eden Suriyeli öğrencilerin ilçe ve okul bazlı verilerinden okulların yer aldığı mahalleler tespit edilerek ilçe ve mahalle dağılış haritaları yapılmıştır. Nitel teknikler; Suriyeli mültecilerle ilgili durum tespiti yapmak amaciyla 20 Suriyeli aileyle derinlemesine mülakat ve katılımcı gözlem tekniği uygulanmıştır. Önceden katılımcılar için sorular hazırlanmış ancak konuşmanın seyrine göre katılımcilara yeni sorularda sorulmuştur. Elde edilen verilerin özgün içeriklerine sadık kalınmış ve söylenilenlerden alıntılar yapılarak analizler yapılmıştır. Araştırma sonuçlarının daha gerçekçi olmasını sağlamak amacıyla mekânsal kümelenmenin fazla olduğu mahallelerde kartopu veya zincir örneklem tekniği kullanılmıştır.

\section{CALISMANIN ÖNEMİ VE AMACI}

Ülkemizde Suriye'deki iç savaştan en fazla etkilenen şehirlerden biri Şanlıurfa'dır. Farklı yaş gruplarında eğitim gören Suriyeli öğrenci sayısının tespit edilmesi Suriyeli mültecilerin Şanlıurfa şehrindeki mekânsal kümelenmelerinin belirlenmesi, dağılışın fazla olduğu mekânlarla sosyo-ekonomik yapı arasındaki bağlantı, yaş gruplarına göre entegrasyon planlamaları yapılabilmesi, Suriyeli mültecilerin şehir üzerine olan sosyoekonomik, kültürel ve mekânsal etkileri bu çalışmayı önemli kılmaktadır.

Suriyeli mültecilerle yüz yüze görüşmeler yapılması sonucunda; göç öncesi durumları, göç süreçleri, beslenme ve 


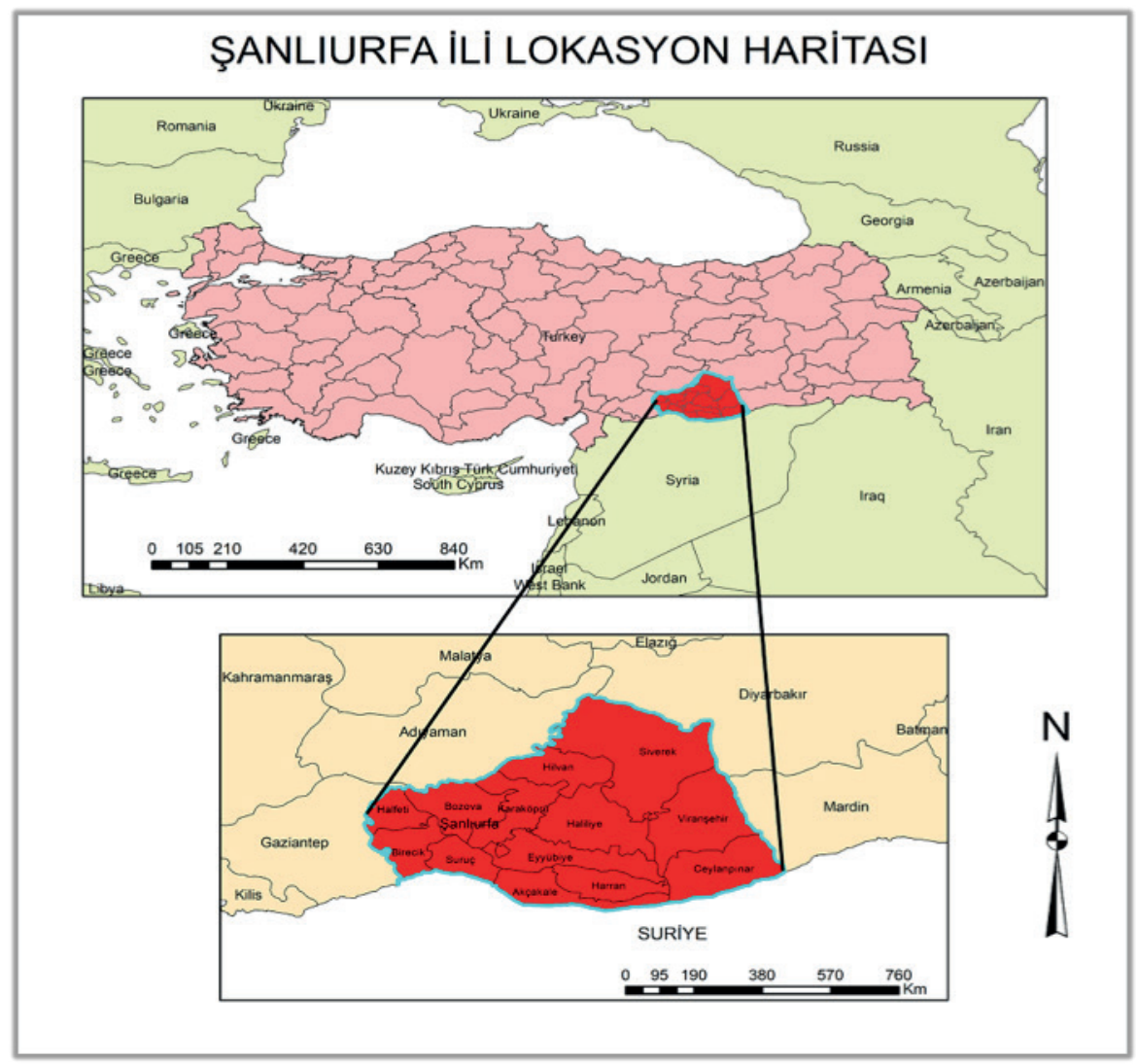

Şekil 1: Araştırma Sahasının Lokasyon Haritası.

barınma durumları, aidiyet, mekânsal algılama, yerel halkla olan ilişkiler ve savaş sonrası geri dönüşle ilgili önemli sonuçlara ulaşılması çalışmayı önemli kılan diğer etmenlerdir.

\section{ARAŞTIRMA ALANI}

Güneydoğu Anadolu Bölgesi’nin Orta Fırat Bölümü’nde yer alan Şanlıurfa, batısında Gaziantep, kuzeybatısında Adıyaman, kuzeydoğusunda Diyarbakır, doğusunda Mardin illeri ve güneyde Suriye Devletiyle komşudur. İl büyükşsehir statüsünde olup idari olarak 13 ilçeden oluşmaktadır. Batıdan doğuya doğru; Birecik, Suruç, Akçakale ve Ceylanpınar Suriye sınırında yer alan ilçelerdir. Araştırma sahası büyükşehir dâhilinde bulunan 13 ilçeyi kapsamaktadır.

\section{ARAŞTIRMA BULGULARI}

\section{1. İllere Göre Suriyeli Mülteci Sayısı}

2011 yllından sonra ülkemize Suriye'den kitlesel mülteci göçlerinin yaşanması nedeniyle uluslararası göç ve göçmenler konusu ülkemizin önemli sorunlarından biri haline gelmiştir.
2013 yılında çıkarılan 6458 sayıl1 "Yabancılar ve Uluslararası Koruma" kanunuyla göç ve göçmenlerle ilgili tüm işlemleri yürütmek üzere Göç İdaresi Genel Müdürlüğü kurulmuştur. Ülkemizde 2011-2019 yılları arasında Suriyeli mülteci sayısı sürekli olarak artmıştır. 2012 yılında geçici koruma altına alınan Suriyeli say1s1 $14.237,2013$ 'te 224.655 , 2014'te 1.519.286, 2015 'te 2.503 .549 , 2016'da 2.834.441, 2017'de 3.426.786, 2018 'de 3.623.192 ve 31.10.2019 tarihi itibariyle 3.680.603'e yükselmiştir (Tablo 1, Şekil 2). Özellikle 2014 y1lı ve sonrasında savaşın şiddetinin artmasına bağlı olarak mülteci sayısında büyük artış olmuştur.

Tablo 1: Türkiye'de Bazı Yıllara Göre Suriyeli Mülteci Sayısı.

\begin{tabular}{cc}
\hline Yıl & Suriye Sayısı \\
\hline 2012 & 14.237 \\
2013 & 224.655 \\
2014 & 1.519 .286 \\
2015 & $2,503.549$ \\
2016 & 2.834 .441 \\
2017 & 3.426 .786 \\
2018 & 3.623 .192 \\
31.10 .2019 & 3.680 .603 \\
\hline
\end{tabular}

Kaynak: https://www.goc.gov.tr/gecici-koruma5638 (31.10.2019) 


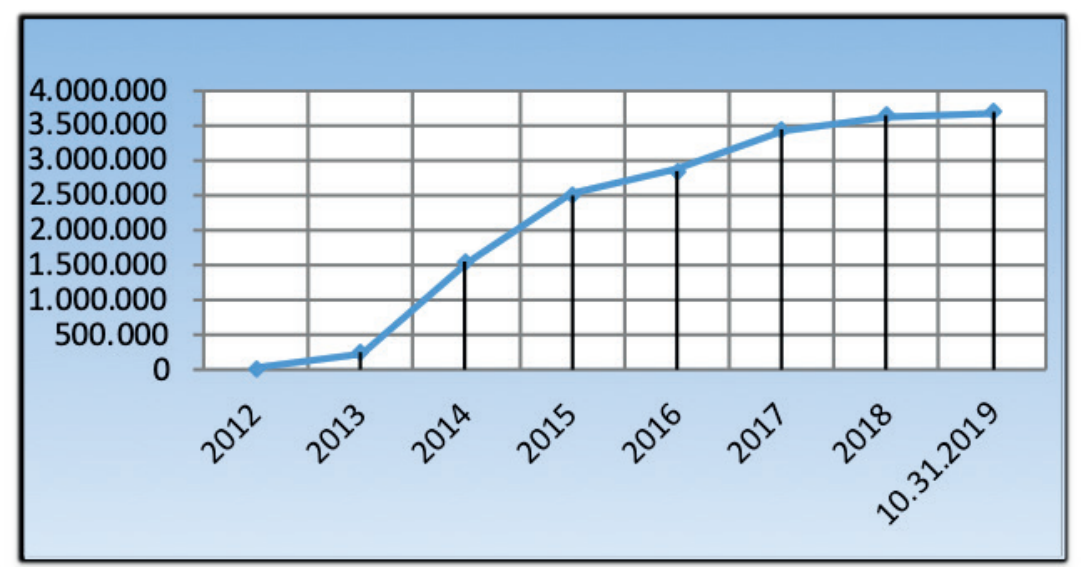

Şekil 2: Türkiye'de Yıllara Göre Suriyeli Sayısı.

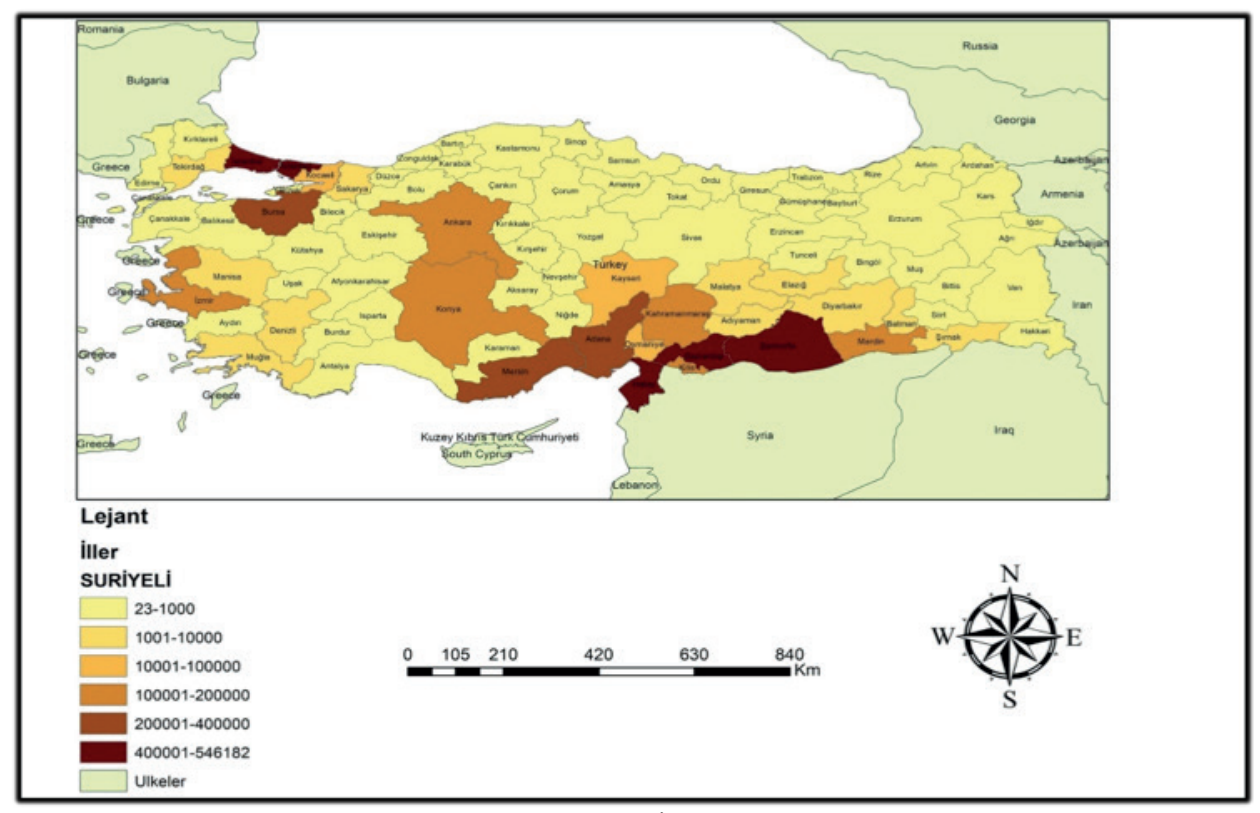

Şekil 3: Suriyeli Mültecilerin İllere Göre Dağılışı, 2019.

31.10.2019 tarihinde yayınlanan bültene göre ülkemizde Suriyeli sayısının en fazla olduğu 10 il arasında Şanlıurfa 4. sıradadır (Tablo 2, Şekil 3). Suriyeli mülteciler sınırda yer alan illerle iş imkânlarının fazla olduğu şehirlerde yoğunlaşmışlardır. 31.10.2019 tarihli son verilere göre Suriyeli mülteci sayısının en fazla olduğu 10 il; İstanbul 549.903, Gaziantep 452.101, Hatay 440.920, Şanlıurfa 429.717, Adana 240.178, Mersin 204.770, Bursa 177.075, İzmir 146.885, Kilis 116.492 ve Konya 109.800'dür.

\section{2. Şanlıurfa'da Suriyeli Mülteciler}

2018 yılı verilerine göre, Şanlıurfa'nın nüfusu 2.035.809'dur. Nüfus il içerisine dengeli bir şekilde dağılmamış olup şehirsel olarak gelişme göstermiş Eyyübiye, Haliliye, Siverek, Viranşehir ve Karaköprü diğer ilçelere göre daha fazla nüfus barındırmaktadır.
Göç İdaresi Genel Müdürlüğü’nün verilerine göre; 31.10.2019 tarihi itibariyle Şanlıurfa'da yaşayan Suriyeli mülteci sayısı 429.717'dir. $\mathrm{Bu}$ durumda ilin nüfusu yaklaşık 2.5 milyondur.

Tablo 2: Suriyeli Mülteci Sayısının En Fazla Olduğu 10 İ (31.10. 2019 tarihi itibariyle)

\begin{tabular}{ccc}
\hline Sıra & il & Suriyeli Sayısı \\
\hline $\mathbf{1}$ & İstanbul & 549.903 \\
$\mathbf{2}$ & Gaziantep & 452.101 \\
$\mathbf{3}$ & Hatay & 440.920 \\
$\mathbf{4}$ & Şanlıurfa & 429.717 \\
$\mathbf{5}$ & Adana & 240.178 \\
$\mathbf{6}$ & Mersin & 204.770 \\
$\mathbf{7}$ & Bursa & 177.075 \\
$\mathbf{8}$ & İzmir & 146.885 \\
$\mathbf{9}$ & Kilis & 116.492 \\
$\mathbf{1 0}$ & Konya & 109.800 \\
\hline
\end{tabular}

Kaynak: https://www.goc.gov.tr/gecici-koruma5638 
İlçelerde ikamet eden Suriyeli sayıları Göç İdaresi Müdürlüğü’nden talep edilmiş ancak veri paylaşımı konusunda sonuç alınamamıştır. $\mathrm{Bu}$ nedenle Suriyeli öğrencilerin eğitim gördükleri okulların mahalle tespitleri yapılarak hem ilçeler hem de ilçe içerisinde mahallelere göre dağılışın fazla olduğu alanlar tespit edilmiştir.

Tablo 3: Şanlıurfa'da Eğitim Gören Suriyeli Öğrenci Sayısı (2018-2019 Eğitim- Öğretim Yılı)

\begin{tabular}{lcccc}
\hline & $\begin{array}{c}\text { Okul Öncesi ve } \\
\text { ilkokul } \\
\mathbf{6 - 1 0} \text { Yaş }\end{array}$ & $\begin{array}{c}\text { Ortaokul } \\
\text { 7-11 Yaş }\end{array}$ & $\begin{array}{c}\text { Lise } \\
\mathbf{1 2 - 1 8} \text { Yaş }\end{array}$ & TOPLAM \\
\hline Akçakale & 7.655 & 2.803 & 744 & $\mathbf{1 1 . 2 0 2}$ \\
Birecik & 1.191 & 444 & 68 & $\mathbf{1 . 7 0 3}$ \\
Bozova & 534 & 77 & 4 & $\mathbf{6 1 5}$ \\
Ceylanpınar & 5.744 & 2.363 & 1.186 & $\mathbf{9 . 2 9 3}$ \\
Eyyübiye & 8.011 & 2.622 & 777 & $\mathbf{1 1 . 4 1 0}$ \\
Halfeti & 330 & 68 & 3 & $\mathbf{4 0 1}$ \\
Haliliye & 8.478 & 3.647 & 1.873 & $\mathbf{1 3 . 9 9 8}$ \\
Harran & 3.007 & 1.549 & 617 & $\mathbf{5 . 1 7 3}$ \\
Hilvan & 274 & 43 & 7 & $\mathbf{3 2 4}$ \\
Karaköprü & 590 & 244 & 209 & $\mathbf{1 . 0 4 3}$ \\
Siverek & 1.031 & 262 & 37 & $\mathbf{1 . 3 3 0}$ \\
Suruç & 7.627 & 2.391 & 385 & $\mathbf{1 0 . 4 0 3}$ \\
Viranşehir & 2.270 & 557 & 72 & $\mathbf{2 . 8 9 9}$ \\
Toplam & $\mathbf{4 6 . 7 4 2}$ & $\mathbf{1 7 . 0 7 0}$ & $\mathbf{5 . 9 8 2}$ & $\mathbf{6 9 . 7 9 4}$ \\
\hline
\end{tabular}

Kaynak: Şanlıurfa ilı Milli eğitim Müdürlüğü, 2019.

Şanlıurfa'da 2018-2019 eğitim öğretim yılında eğitim gören farklı yaş gruplarında öğrenci sayısı 69.794 'tür. Sınıf seviyelerine bakıldığında; 1-4 arası sınıflarda eğitim gören 46.742, 5-8 aras1 17.070 ve 9-12 arasında 5.982' dir (Tablo 3). 1-4 arasında eğitim gören öğrenciler 6-10 yaş aralığında olan çocuklardan oluşmaktadır. $\mathrm{Bu}$ bağlamda bu yaş aralığındaki öğrenciler toplam öğrenci sayısının \%67'sini oluşturmaktadır. 5-8 arasında eğitim gören öğrenciler 7-11 yaş aralığında olup toplam öğrenci sayısının \%24'dür. 9-12 arası sınıf seviyeleri 15-18 yaş aralığında olan öğrencilere denk gelip toplam öğrenci içerisindeki payı \%9'dur (Şekil 4). Sonuç olarak 6-10 yaş aralığında bulunan öğrenci sayısının fazla olması savaştan kaçanların önemli bir kısmını çocukların oluşturduğunu gösterir.

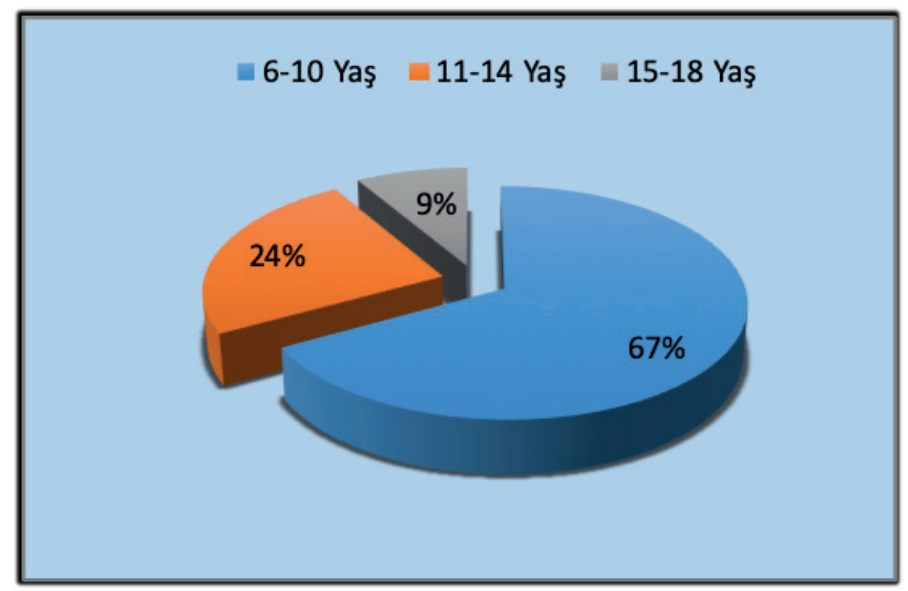

Şekil 4: Şanlıurfa İlinde Yaş Gruplarına Göre Suriyeli Öğrenci Oranları.
Öğrenci sayılarının en fazla olduğu ilçelere bakıldığında; Haliliye 13.998, Eyyübiye 11.410, Akçakale 11.202, Suruç 10.403 ve Ceylanpınar'da 9.293 Suriyeli öğrenci bulunur. Öğrenci sayısının en az olduğu ilçeler; Hilvan 324, Halfeti 401 ve Bozova 615'tir. Bu duruma göre; Suriyeli mülteci sayısının en fazla olduğu ilçe Haliliye, dağılışın fazla olduğu diğer ilçeler ise, Eyyübiye, Akçakale, Suruç ve Ceylanpınar'dır. Suriyeli mültecilerin en az dağılış gösterdikleri ilçeler de, Hilvan, Halfeti ve Bozova ilçeleridir (Şekil 5). Ceylanpınar, Akçakale ve Suruç ilçeleri Suriye sınırında yer aldığından ayrıca akrabalık bağlarının da etkisiyle Suriyeli mültecilerce göç sürecinde geçiş yeri olarak kullanılan ilçelerdir. Ancak Haliliye ve Eyyübiye ilçeleri Şanlıurfa'da sosyo-ekonomik olarak daha fazla imkân sunduğundan mültecilerce kalıcı yer olarak görülmektedir.

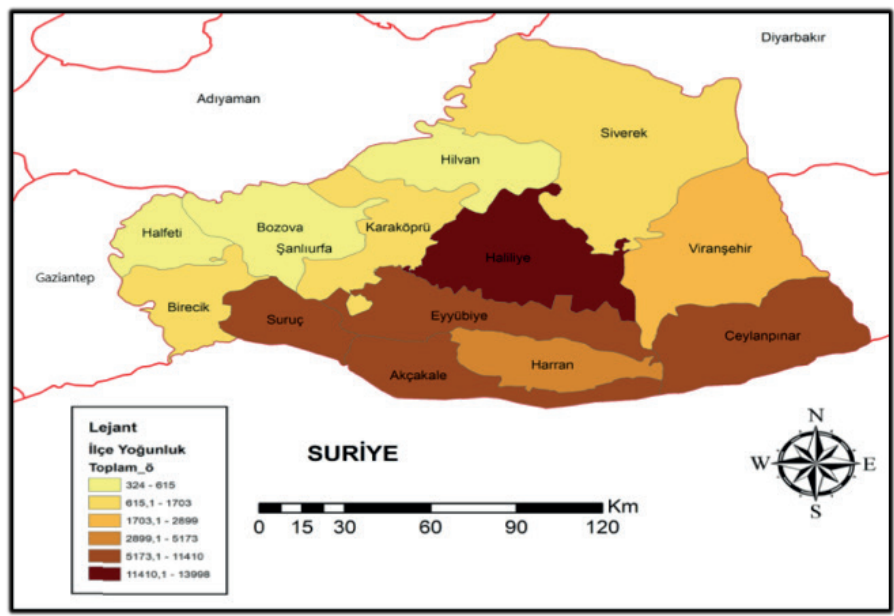

Şekil 5: Şanlıurfa'da İlçelere Göre Suriyeli Öğrenci Dağılışı.

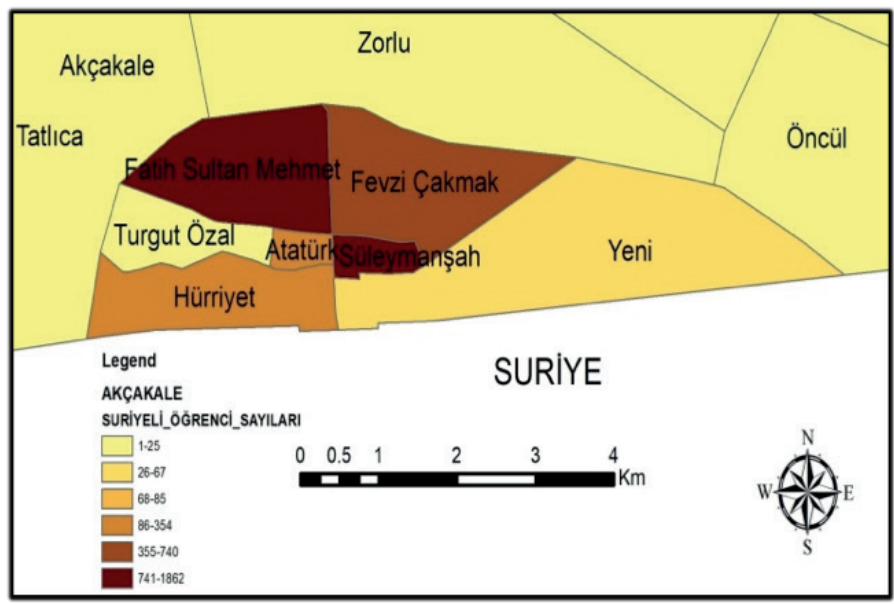

Şekil 6: Akçakale İlçesinde Suriyeli Öğrencilerin En Fazla Dağılış Gösterdiği Mahalleler.

Akçakale ilçesi Suriye sınırında yer almaktadır. Suriye tarafında Tel Abyad şehri bulunmaktadır. İç savaş başladıktan sonra mültecilerin yoğun şekilde ülkemize giriş yaptıkları sınır alanlarından biri Akçakale'dir. İlçede 2013 yılında mülteciler 
için çadır kent kurulmuş 2019 yılında da çadır kent tamamıyla boşaltılmıştır. Şekil 6 incelendiğinde; Akçakale'de Suriyeli mülteciler Süleymanşah, Fatih Sultan Mehmet ve Fevzi Çakmak mahallelerinde yoğun şekilde dağılış göstermişlerdir. Hürriyet, Atatürk ve Yeni mahallelerinde ise Suriyeli mülteciler daha az sayıdadir.

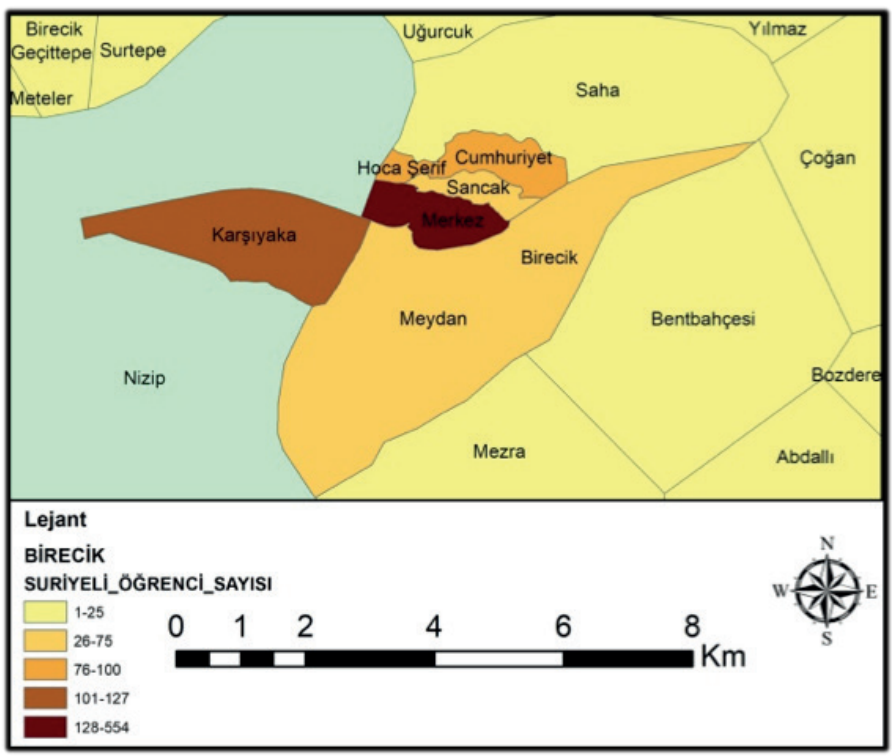

Şekil 7: Birecik İlçesinde Suriyeli Öğrencilerin En Fazla Dağılış Gösterdiği Mahalleler.

Birecik ilçesi sosyo-ekonomik olarak pek gelişme göstermemiştir. Bu nedenle Suriyeli mülteciler tarafından çok fazla tercih edilmemiştir. İş sahalarının yoğunlaşması aynı zamanda eski tip konutların yer alması nedeniyle Merkez ve Karşıyaka dağılışın fazla olduğu mahallelerdir. Hacı Şerif, Cumhuriyet, Meydan ve Sancak mahallelerinde ise Suriyeli mülteci sayısı daha azdır (Şekil 7).

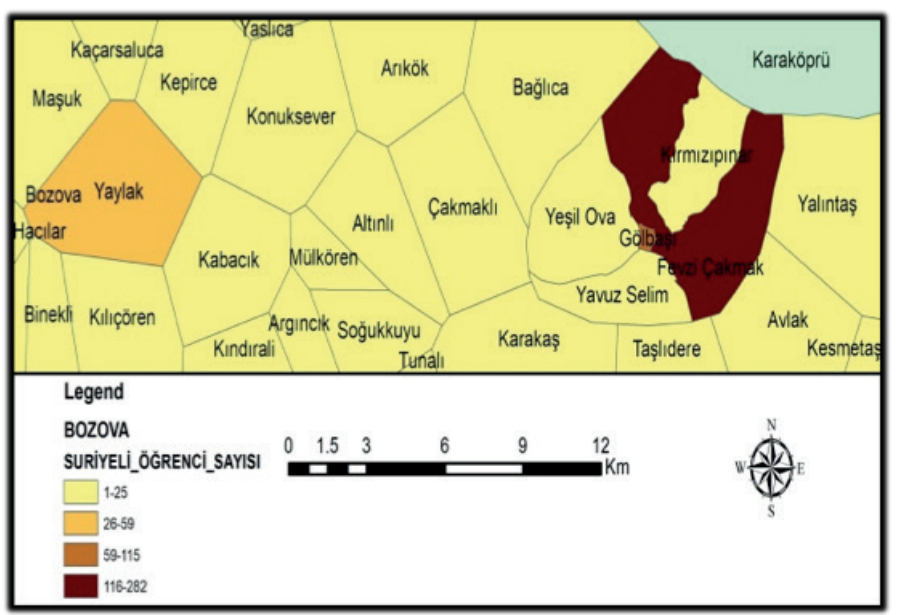

Şekil 8: Bozova İlçesinde Suriyeli Öğrencilerin En Fazla Dağılış Gösterdiği Mahalleler.
Bozova, Şanlıurfa'nın pek fazla gelişim göstermemiş ilçelerindendir. Suriyeli mülteci sayısının çok fazla olmadığı ilçede, Şehir merkezinde yer alan Gölbaşı ve Fevzi Çakmak mahalleleriyle eski bir belde merkezi olan Yaylak dağılışın fazla olduğu mahallelerdir (Şekil 8).

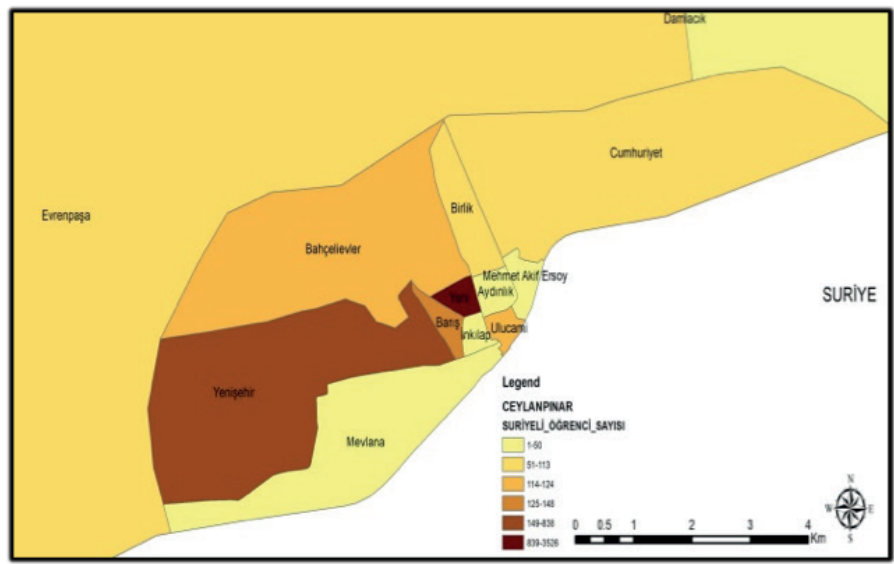

Şekil 9: Ceylanpınar İlçesinde Suriyeli Öğrencilerin En Fazla Dağılış Gösterdiği Mahalleler.

Sınırda yer alan diğer bir ilçe Ceylanpınar'dır. Sınırın Suriye tarafında Resulayn şehri bulunur. İlçede tarım dışında herhangi bir sektör gelişmemiştir. Suriye' deki iç savaş sonrası mültecilerin akın etmesi nedeniyle 2013 yılında ilçede çadır kent kurulmuş ancak 2019 yılında çadır kent tamamen boşaltılmıştır. Yeni, Yenişehir, Barış ve Bahçelievler dağılışın en fazla olduğu mahallelerdir. Cumhuriyet, Birlik, Evrenpaşa ve Ulucami mahalleleri dağılışın az olduğu mahallelerdir (Şekil 9).

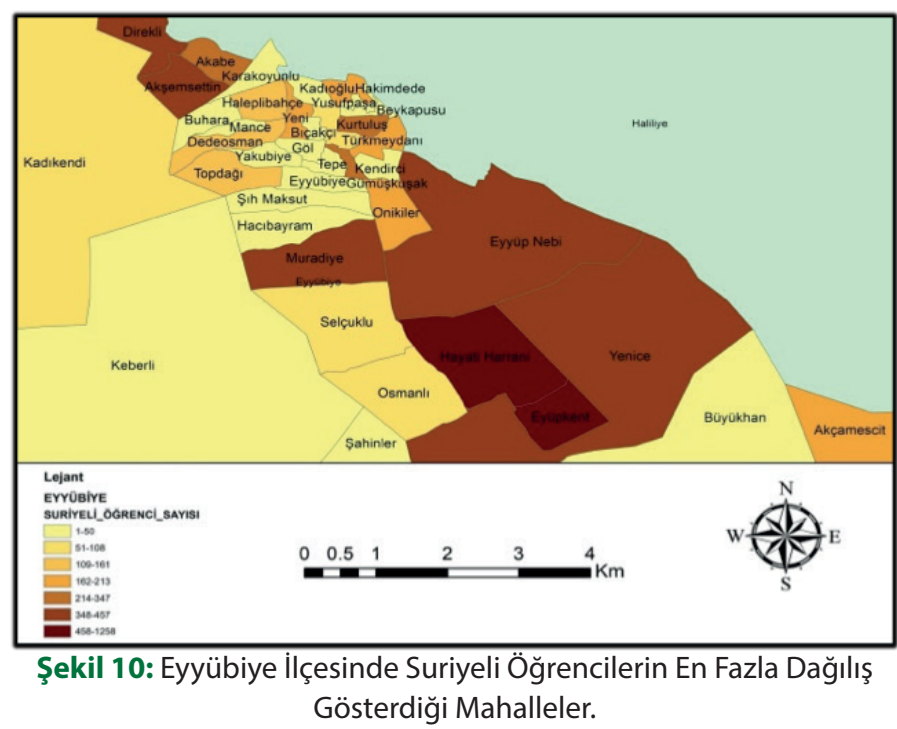

Şanlıurfa'da Suriyeli öğrenci sayısının en fazla olduğu ikinci ilçe Eyyübiye'dir. Tek katlı evlerin varlığı nedeniyle konut kiralarının düşük olduğu ilçede Suriyeli mülteciler bazı mahalelerde kümelenmiştir. Şanlıurfa'nın merkez ilçelerinden 
biri olan Eyyübiye'de Suriyeli mültecilere ait iş yerleri sayısı da fazladır. Eyyüpnebi, Hayati Harrani, Eyüpkent, Akşemsettin, Yenice, Muradiye, Direkli ve Kurtuluş Suriyeli mültecilerin en fazla kümelendiği mahalelerdir (Şekil 10).

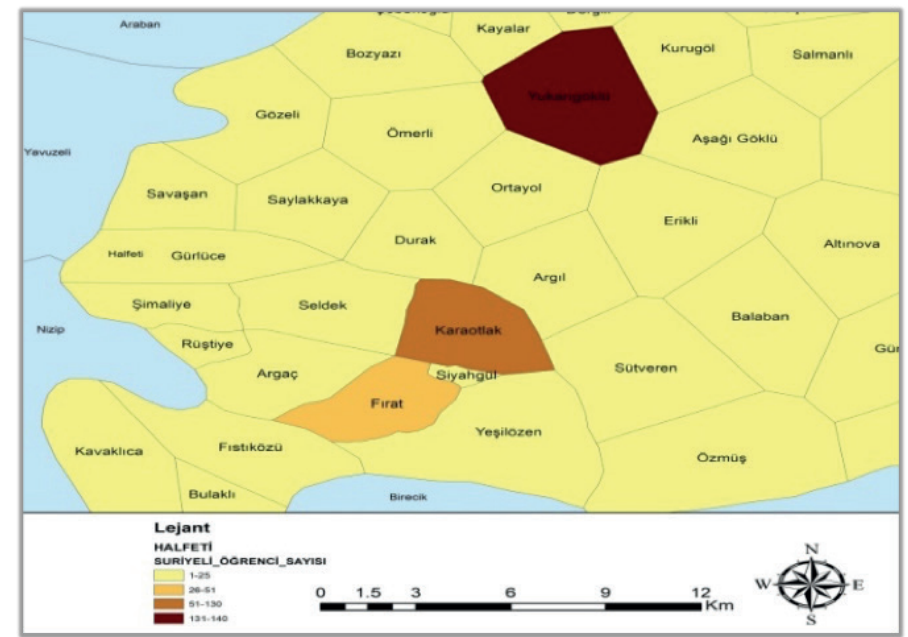

Şekil 11: Halfeti İlçesinde Suriyeli Öğrencilerin En Fazla Dağılış Gösterdiği Mahalleler.

Suriyeli öğrenci sayısının en az olduğu ilçelerden biri Halfeti'dir. Birecik barajının tamamlanmasıyla beraber şehir merkezi şuanki mevcut yerine taşınmıştır. İlçenin eski alanı turizm amaçlı kullanılmakta olup insanlar için önemli bir geçim kaynağı haline gelmiştir. Ekonomik olarak çok fazla gelişmediğinden Suriyeli mültecilerin tercih etmediği ilçelerdendir. Yukarugöklü, Karaotlak ve Fırat mahalleleri dağılışın fazla olduğu mahallelerdir. (Şekil 11).

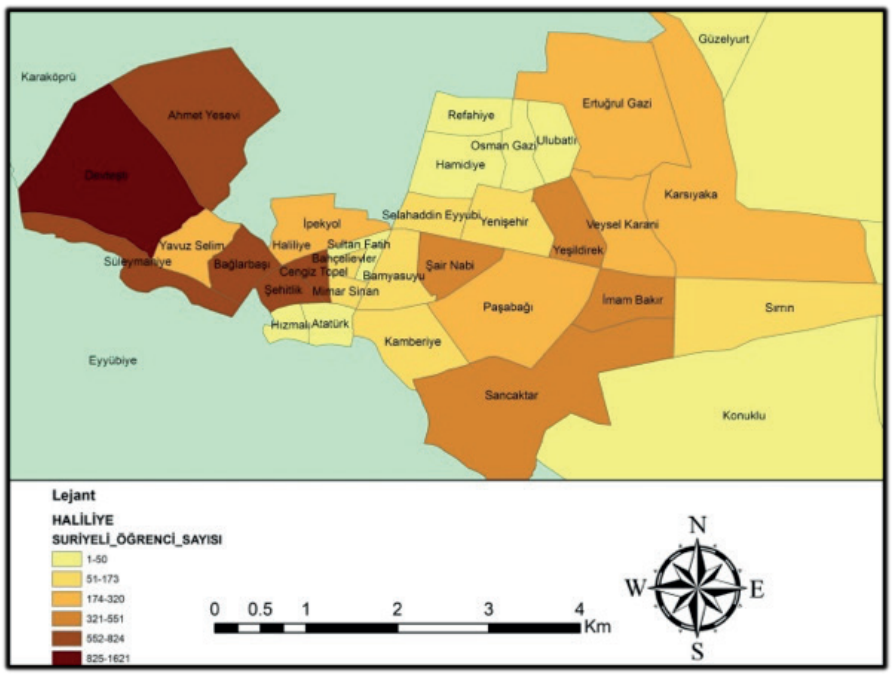

Şekil 12: Haliliye İlçesinde Suriyeli Öğrencilerin En Fazla Dağılış Gösterdiği Mahalleler.

Suriyeli öğrenci sayısının en fazla olduğu ilçe Haliliye'dir. İlçenin merkezi iş alanlarına yakın mahallelerde kümelenen Suriyeli mülteciler genellikle tek katlı ve kiraların yüksek olmadığ1 alanları tercih etmişlerdir. Devteşti, Ahmet Yesevi, Süleymaniye, Bağlarbaşı, Şehitlik, Cengiz Topel, Şair Nabi, Yeşildirek, İpekyolu, Sancaktar, İmam Bakır ve Yavuz Selim mahallelerinde yoğun şekilde yaşamaktadır (Şekil 12).

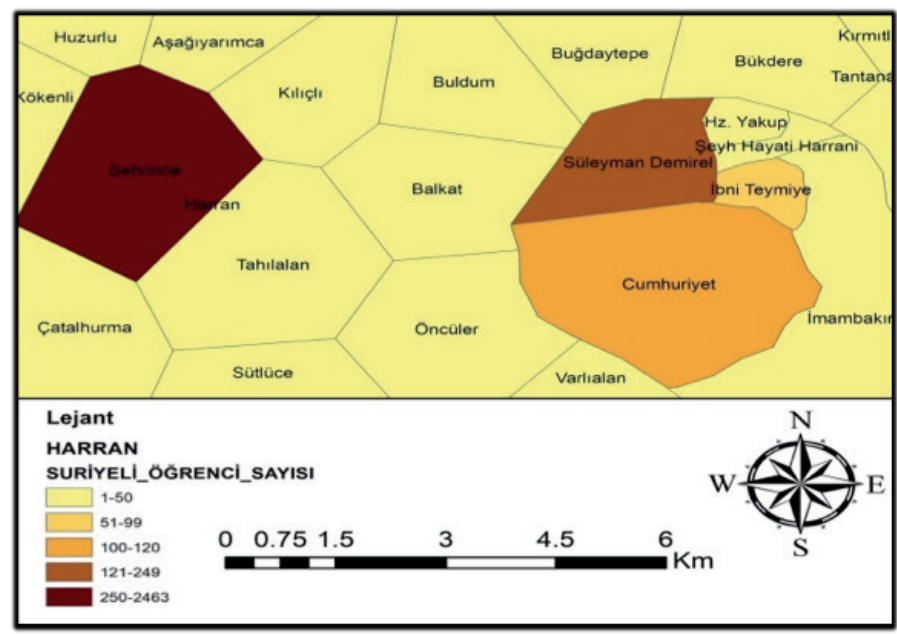

Şekil 13: Harran İlçesinde Suriyeli Öğrencilerin En Fazla Dağılış Gösterdiği Mahalleler.

GAP kapsamında sulama kanallarının yapılmasıyla tarımda önemli gelişim göstermesi beklenen ilçelerden biri olan Harran, akrabalık bağları, sınıra yakınlık, mevsimlik iş olanaklaarı ve kültürel benzerlik nedeniyle Suriyeli mültecilerin tercih ettiği ilçelerdendir. Suriyeli öğrenciler daha çok merkez mahallelerde toplanmışlardır. Süleyman Demirel, Cumhuriyet ve İbni Teymiye dağılışın fazla olduğu mahallelerdir. Ayrıca Sehrince mahallesinde konteyner kent kurulduğundan öğrenci sayısı fazladır (Şekil 13).

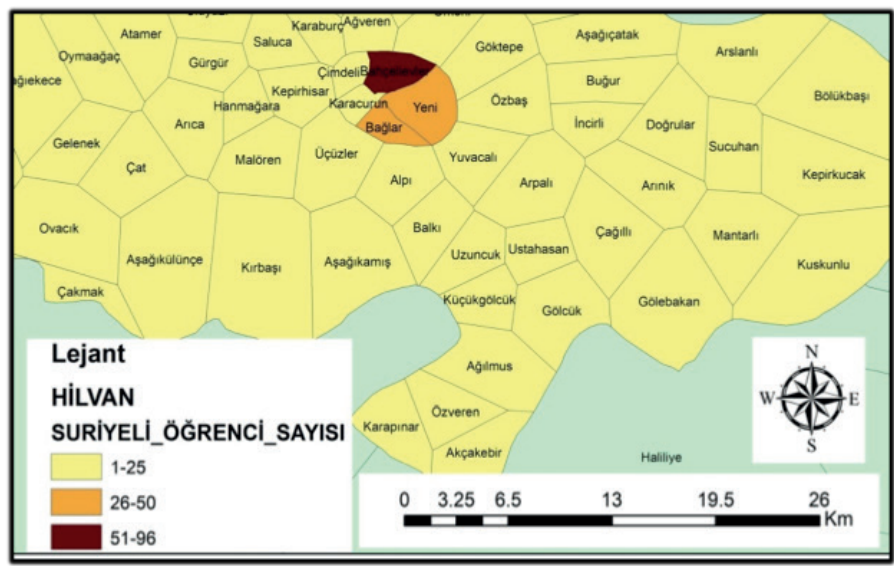

Şekil 14: Hilvan İlçesinde Suriyeli Öğrencilerin En Fazla Dağılış Gösterdiği Mahalleler.

Suriyeli öğrenci sayısının en az olduğu ilçe Hilvan'dır. İlçenin ekonomik olarak pek gelişmemiş olması nedeniyle çok fazla tercih edilmemiştir. Bahçelievler, Yeni ve Bağlar Suriyeli mültecilerin yaşadıkları şehir merkezindeki mahallelerdir (Şekil 14). 


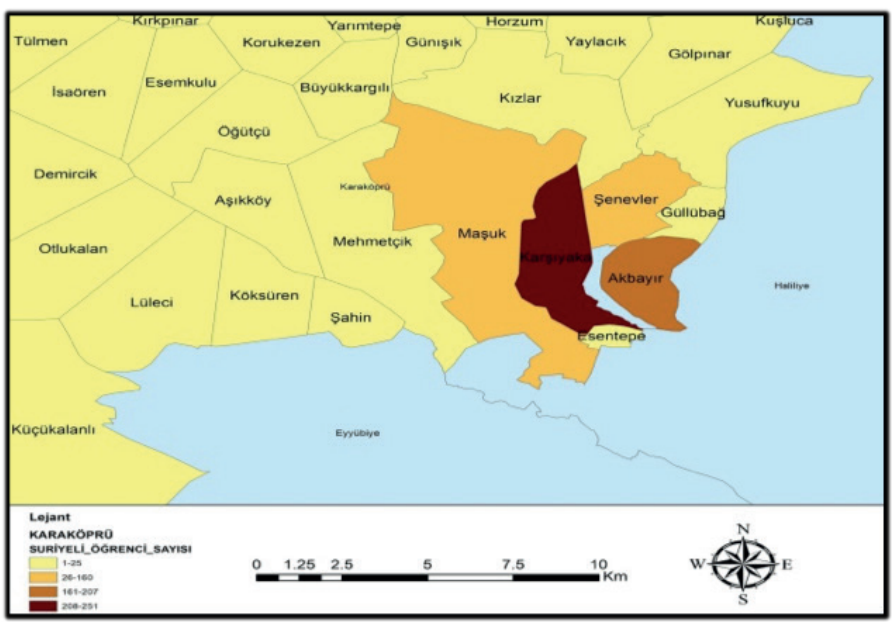

Şekil 15: Karaköprü İlçesinde Suriyeli Öğrencilerin En Fazla Dağılış Gösterdiği Mahalleler.

Suriyeli öğrenci sayısının az olduğu diğer bir ilçe Karaköprü'dür. Karaköprü ilçesi son yıllarda şehirsel olarak önemli gelişim göstermiş, çok katlı lüks konutların inşa edildiği, gelir düzeyi orta ve yüksek olan insanların tercih ettiği ve kiraların çok yüksek olduğu bir ilçedir. Bu nedenle Suriyeli mülteciler tarafindan pek tercih edilmemekle beraber Maşuk, Karşıyaka, Akbayır ve Şenevler mahallelerinde yaşayan Suriyeliler bulunmaktadır (Şekil 15). Bu ilçede yaşayan Suriyeli mülteciler savaş öncesi geliri yüksek olanlardan oluşmaktadır.

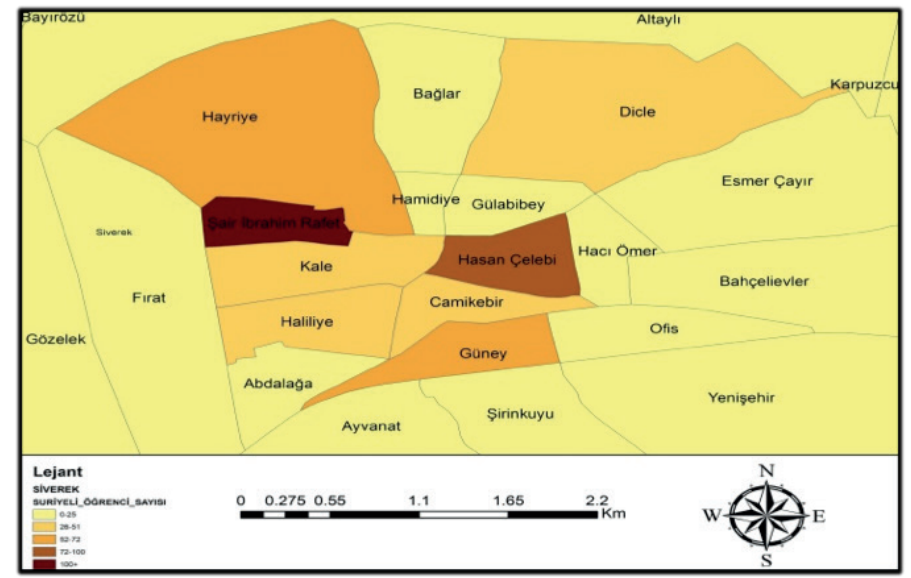

Şekil 16: Siverek İlçesinde Suriyeli Öğrencilerin En Fazla Dağılış Gösterdiği Mahalleler.

Suriyeli öğrenci sayısının en az olduğu ilçelerden bir diğeri Siverek'tir. Sınıra uzak ve iş imkanları kısıtlı olduğundan bu ilçe Suriyeli mültecilerce tercih edilmemiştir. İlçede yaşayan Suriyeli mülteciler; Şair İbrahim Rafet, Hasan Çelebi, Hayriye ve Güney mahallelerinde daha çok kümelenmiştir (Şekil 16).

Suriye sınırında yer alan ve Suriyeli öğrenci sayısının fazla olduğu ilçelerden biri de Suruç’tur. Harran ilçesinde olduğu gibi

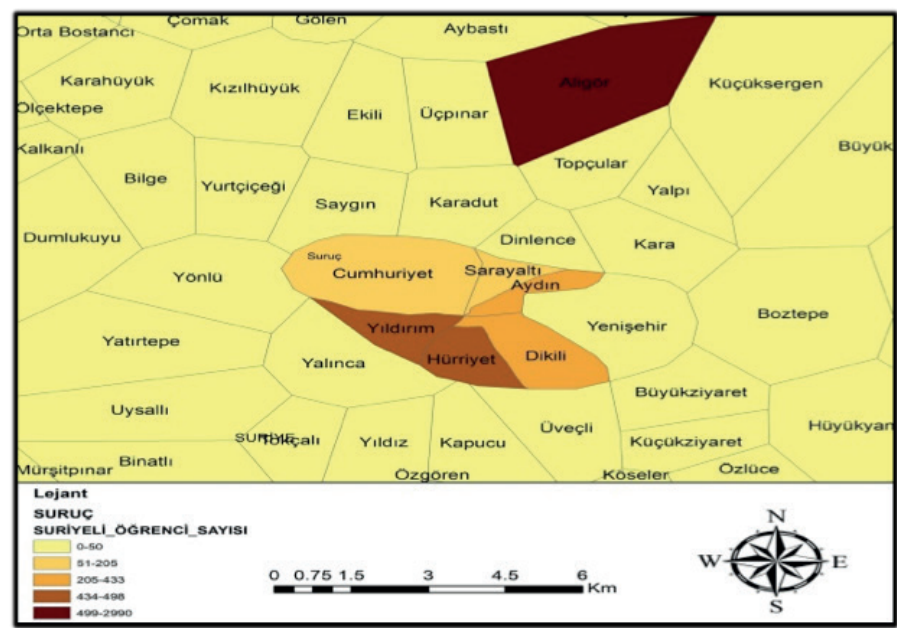

Şekil 17: Suruç İlçesinde Suriyeli Öğrencilerin En Fazla Dağılış Gösterdiği Mahalleler.

GAP'la beraber tarımsal üretimde sulama yapılabildiğinden mevsimlik iş olanakları artmıştır. Sınırın Suriye tarafında Kobani şehri bulunur. Bu ilçenin sınırda bulunması, akrabalık bağları ve kültürel benzerlik nedeniyle ilçe yoğun mülteci göçüne uğramıştır. Aligör Mahallesi yakınında Dünya'nın en büyük çadır kentlerinden biri kurulmuştur. Aligör başta olmak üzere Hürriyet, Yıldırım, Dikili, Aydın, Cumhuriyet ve Sarayaltı dağılışın en fazla olduğu mahallelerdir (Şekil 17).

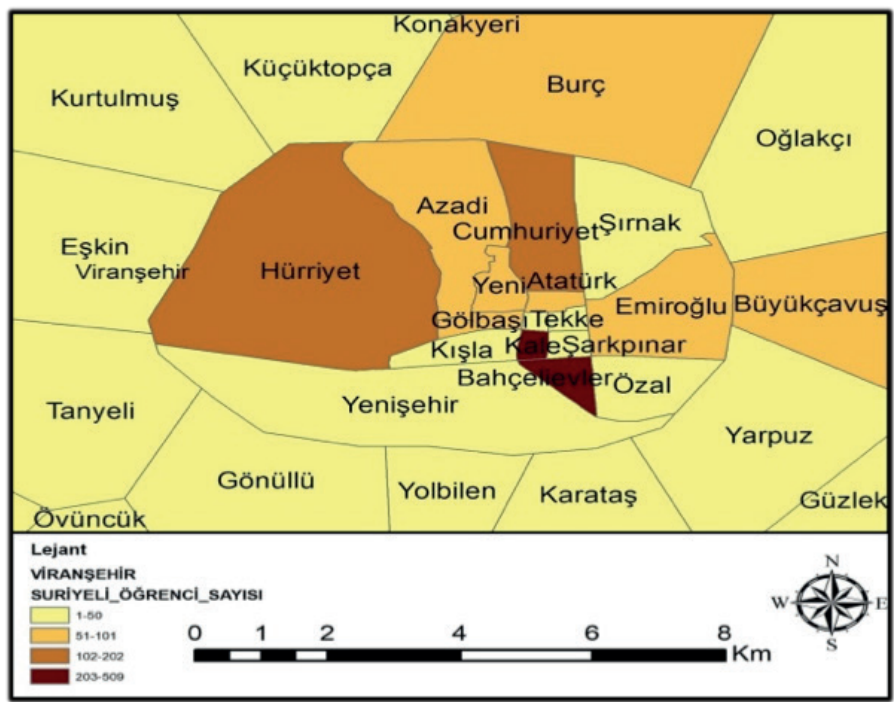

Şekil 18: Suruç İlçesinde Suriyeli Öğrencilerin En Fazla Dağılış Gösterdiği Mahalleler.

Suriyeli öğrenci sayısının çok fazla olmadığı bir diğer ilçe Viranşehir'dir. İlçenin tarihi İpek Yolu güzergahında yer alması nedeniyle tarımın yanı sıra ticarette diğer ilçelere göre daha fazla gelişmiştir. Şehir merkezinde ve iş sahlarına yakın Kale, Bahçelievler, Hürriyet, Cumhuriyet, Burç ve Büyükçavuş mahallelerinde dağılış fazladır (Şekil 18). 


\subsection{Suriyeli Mültecilerin Mevcut Durum Analizi}

Göç olgusu yalnızca mekânlar arasında yaşanan değişim süreci değildir aynı zamanda sosyal, kültürel, siyasal ve ekonomik olarak toplumsal yapıyı etkileyen bir harekettir (Tümtaş, 2009: 113). Suriyeli mültecilerin göç öncesi durumları, göç süreçleri, ülkemize olan sosyal, ekonomik ve kültürel etkilerini tespit etmek amaciyla 20 Suriyeli mülteciyle önceden hazırlanmış sorular ve konuşmanın seyrine göre yeni sorularla barındıkları mekânlarda derinlemesine görüşme tekniği uygulanmıştır. Suriyeli mülteci sayısının en fazla dağılış gösterdiği Haliliye ve Eyyübiye ilçelerinde mekânsal kümelenmenin olduğu mahallelerde kartopu ve zincir örneklem tekniği uygulanarak görüşmeler gerçekleştirilmiştir. Katılımcıların talepleri doğrultusunda ve güvenlik gerekçesiyle isimleri gizli tutularak durum değerlendirmesi yapılmıştır.

21-68 yaş aralığında 12 kadın, 8 erkek olmak üzere 20 aileyle ev ortamında mülakat yapılmıştır. Katılımcıların 3'ü ilkokul, 8'i lise ve 9'u üniversite mezunudur. Savaş öncesinde katılımcılardan 1'i avukat, 2'si mühendis, 4'ü öğretmen, 2'si memur, 1'i gazeteci, 4'ü esnaf, 2'si öğrenci ve 4'ü ev hanımı durumundaydı.

Mülakat yapılan Suriyeli mülteciler Deyrizor, Rakka, Haseke, Halep ve Kobani şehirlerinden ülkemize göç etmişlerdir. Ülkemizin uyguladığı “Açık Kapı" politikası gereği katılımcıların tümü sınırı rahat bir şekilde geçtiklerini ve kamplarda kalmadıklarını belirtmiştir. Sosyal ağlar göç sürecinde önemli işlevlere sahiptir (Boyd, 1989: 642; Epstein, 2008: 568; Munshi, 2003: 1). Nitekim katılımcılar akrabalık ve hemşeri ağlarını kullandıklarını ve ülkemize yerleşmekte zorlanmadıklarını belirtmiştir. Ağların kullanılması Suriyelilerin mekâna olan aidiyetini de kolaylaştırmıştır. 3 katılımcı çatışmalar nedeniyle savaşta yaralanmış ve tedavi edilmek üzere ülkemize getirilmiş̧ir. Katılımcıların ülkemize gelişleri 4-6 yıl arasındadır. 6 katılımcı 1. derecede, 14 katılıme da 2. dereceden akrabalarını savaşta kaybetmiş̧tir.

\subsection{Sosyo-Ekonomik Durum}

Suriyeli mültecilerin yoğun olarak yaşadığı illerde sosyal ve ekonomik hayat üzerinde önemli etkileri olmuştur. Mülakat yapılan görüşmecilerin tümü beslenme, giyim ve barınma ihtiyaçlarını kendi imkânlarıyla karşılamaktadır. Görüşme yapılan mültecilerin; 4'ü Öğretmen, 3'ü bakkal, 5'i seyyar satıc1, 3'ü dönerci, 2'si temizlik elemanı, 2'si inşaat iş̧̧isi ve 1'i kuran kursu öğreticisidir. Sağlık ve eğitim harcamaları devlet tarafından karşılanmakta olup Suriyeli öğrenciler 2018-2019 eğitim öğretim yılına kadar Geçici Eğitim Merkezlerinde ve Türk öğrencilerin olduğu okullarda, 2019-2020 eğitim öğretim yılında ise GEM'ler kapatılarak tüm Suriyeli öğrencilere Türk okullarında açılan uyum sinıflarında Türk ve Arap hocalar tarafından eğitim verilmeye başlanmıştır. Uyum sınıflarının açılması Türkçe'nin daha hızlı öğrenilmesini sağlayacağından Suriyeli mültecilerin uyum süreçlerini hızlandıracaktır.

Ülkemizde son y1llarda yaşanan ekonomik durgunluğun sorumlusu olarak Suriyeli mülteciler görüldüğünden Suriyeli sayısının fazla olduğu şehirlerde Suriyeli mültecilere karşı münferit veya kitlesel tepkiler oluşabilmektedir. Şanlıurfa'da Suriyelilere ait işyerlerinin hızla artması, yevmiyeli inşaat işlerinde ücretlerin düşmesi ve Suriyelilerin ucuz iş gücü olarak görülmesi tepkilerin nedenlerindendir.

\subsection{Aidiyet}

Mekândan bağımsız bir kimlik düşünülemeyeceği gibi kimliksiz bir mekânda düşünülemez. (Proshanksy, 1978: 160). Aidiyet ve mekan arasındaki ilişki üç şekilde ortaya çıkar: Lokasyon, bireysel ve toplumsal boyut (Uysal, 2015: 63) Lokasyon boyutu yalnızca mekanlar arasında yaşanan değişim değildir. Nitekim Suriyeli mültecilerin Türkiye'yi tercih etmesinde coğrafi yakınlığın yanı sıra kültürel bağlar da etkili olmuştur. Bireysel ve toplumsal boyutlar ise kişinin iç dünyasını

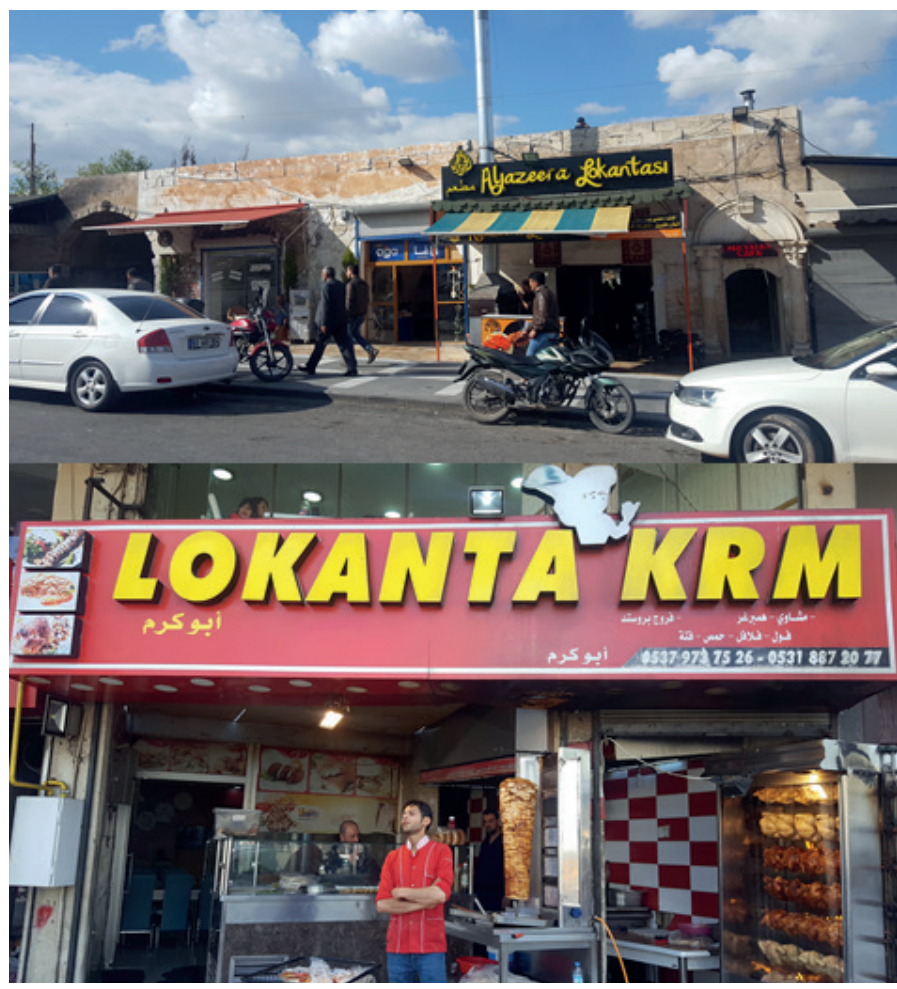

Foto 1: Suriyeli Mültecilere Ait İşyerleri, Şehit Nusret Caddesi. 
duygu ve düşüncelerinde hissettikleridir. Suriyeli mülteciler kendi kimliklerini ülkemizde rahatça yaşayabildiklerini, aidiyet duygusunun yüksek olduğunu kendilerini ait restoranlar, tatlıcılar, kuruyemişçiler, firınlar, berber dükkanları, kafeler, kuyumcular vb. işyerleri bulunması sosyal ve mekânsal aidiyet duygusunun gelişmesine katk1 sağlayabilmiştir (Foto 1).

Suriyeli mültecilere ait işyerleri Şehit Nusret Caddesi ve Atatürk Bulvarı etrafında, Sarayönü ve Divanyolu Caddeleri, Haşimiye Meydan'ında kümelenmiştir. 2019 Temmuz ayında İçişleri Bakanlığı'nın genelgesiyle Suriyeli mültecilere ait Arapça yazılan işyeri isimleri kaldırılarak Türkçe tabelalar zorunlu hale getirilmiştir.

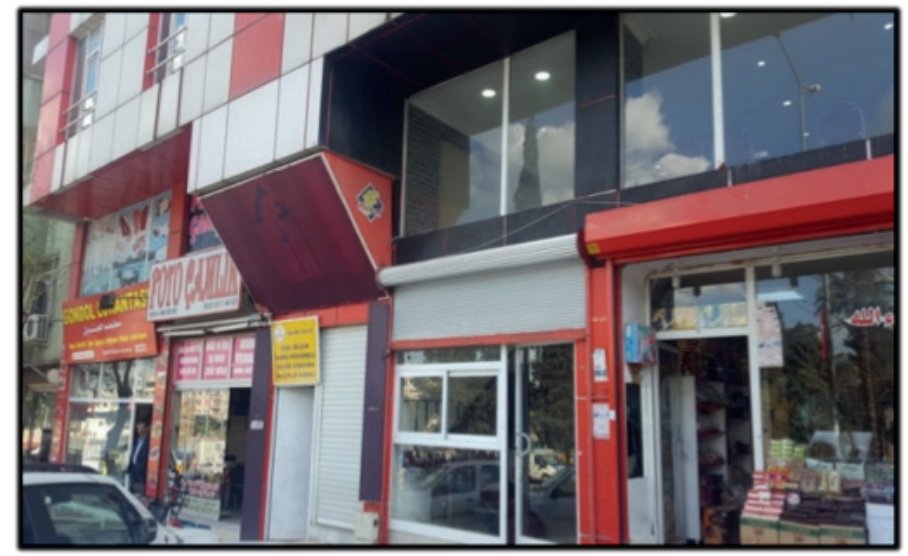

Foto 2: Şehit Nusret Caddesi'nde Suriyeli Mültecilere Ait işyerleri.

Katılımcılar 2017 yılından önce savaştan kaçıp gelmelerinin etkisiyle yerel halkın daha yardımsever ve sıcak ilişkiler kurduklarını ancak ülkemizde yaşanan sosyal, siyasal ve ekonomik gelişmelerin etkisiyle 2017 yılından sonra komşuluk ilişkilerinin zayıfladığını, ekonomideki durağanlaşmadan kendilerinin sorumlu tutulmasından dolayı dışlanmaya başladıklarını ifade etmişlerdir. Dışlanmayı en fazla hissedenlerin de gençler olduğu anlaşılmıştır.

\subsection{Sosyal ve Mekânsal Uyum Süreci}

Göç sürecinde kaynak alandan hedef alana yerleşinceye kadar olan süreçte çeşitli uyum zorlukları yaşanabilmektedir. Mekânsal uyum sürecini zorlaştıran en önemli sorun iletişim yani dil sorunudur. Nitekim katılımcıların tümü iletişim konusunda zorlandıklarını ifade etmişlerdir. Şanlıurfa'daki yerel halkla Suriyeli mülteciler benzer kültüre sahip olmaları ve dini olarak aynı mezhebi paylaşmaları uyum sürecini kolaylaştıran sosyal etmenler olarak katılımcılar tarafından dile getirilmiştir. Maddi sıkıntılar, işsizlik ve birden çok çekirdek ailenin aynı evi paylaşmak zorunda olmaları uyum sürecini zorlaştıran ekonomik faktörler olarak tespit edilmiştir. Suriyeli mültecilerin birbirlerine yakın yerlerde ikamet etmeleri yerel halkla olan etkileşimi de azaltmaktadır. Ayrıca bazı metruk meskenlerin maddi yetersizlik nedeniyle Suriyeliler tarafindan konut olarak kullanılması da uyum sürecini zorlaştırmıştır (Foto 3).

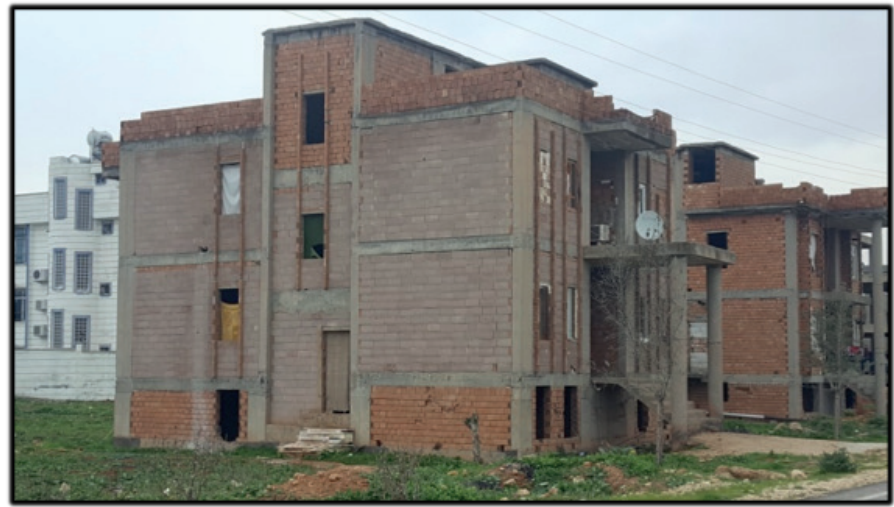

Foto 3: Suriyeli Mültecilerin kaldığı bazı Metruk Binalar, Dağeteği Mahallesi.

Katılımcıların barınma amaçlı kullandıkları konutlar sosyoekonomik yapıyla ilişkili olup evler; 100-140 m² genişlikte, sobalı, kira miktarı 600-900 TL aralığında, evlerde yaşayan aile bireyi sayısı ise 6-17 kişi arasında değişmektedir. Bamyasuyu, Devteşti, Süleymaniye, Bağlarbaşı, Karşıyaka, Hayatı Harrani, Eyüpkent, Eyüpnebi, Muradiye, Akşemseddin, Cengiz Topel gibi mahallelerde tek veya iki katlı konutların bulunması ve kira ücretlerinin bazı mahallelere göre daha düşük olması nedeniyle mekânsal kümelenmeler ortaya çıkmıştır.

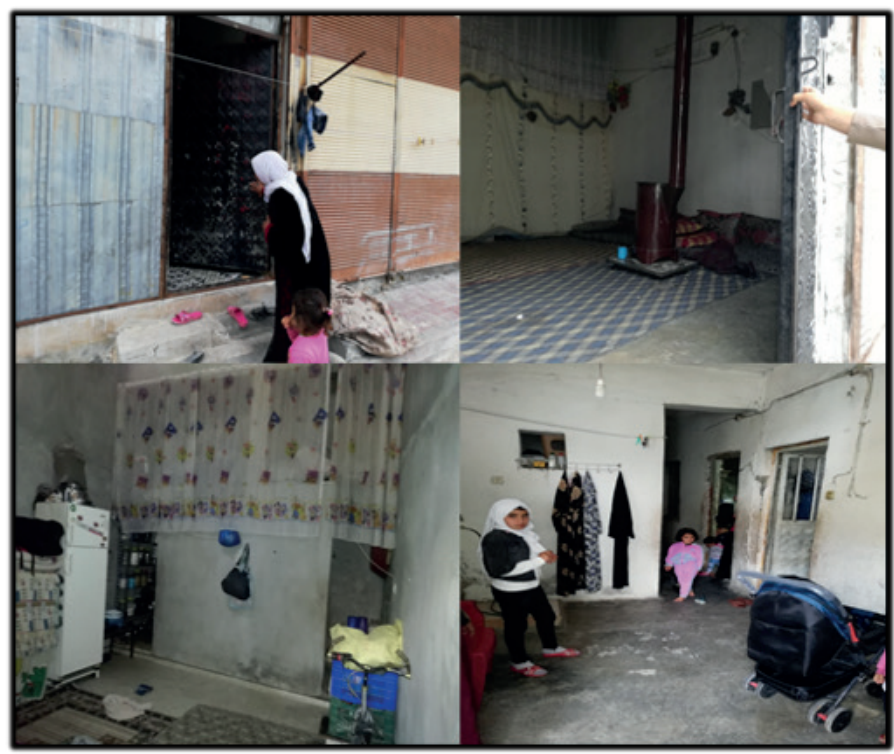

Foto 4: Suriyeli Mültecilerin Yaşadığı Meskenlerden Örnekler, Hayatı Harrani Mahallesi. 


\subsection{Geri Dönüş}

2011 y1lından sonra ülkemize başlayan Suriyeli mülteci göçleri geçen 8 yıllık sürede iç savaşın seyrine bağlı olarak bazen artmış bazen de durağanlaşmıştır. Ülkemizin sınırda güvenli bölge oluşturmak amacıyla gerçekleştirdiği Zeytin Dalı ve Barış Pınarı askeri harekâtları Suriyeli mülteci göçünün tam olarak bitirmemekle beraber azalmasını sağladığı gibi ülkemizde bulunan mültecilerin de ülkelerine dönmeleri için önem arz etmiştir. Katılımcılar, savaş sonrası Suriye'ye geri dönüş veya başka bir ülkeye yerleşme konusunda sıcak bakmadıkları görülmüştür. 18 katılımcı savaş bitse dahi Suriye'ye geri dönmeyi düşünmediklerini, yaşları 50 ve üstü olan 2 katılımcı ise güvenliğin sağlanması durumunda geri dönebileceklerini ifade etmiştir. $\mathrm{Bu}$ bağlam da anlaşılmaktadır ki, Suriyeli mülteciler ülkemizde toplumsal yapının önemli bir parçası olmaya başlamış ve zorunlu geri dönüş gibi politikalar uygulanmadığı düşünülürse gelecekte sosyolojik olarak önemli konulardan biri olacaktır.

\section{TARTIŞMA VE SONUÇ}

Suriyeli mülteciler 2011 y1lında başlayan iç savaş nedeniyle ülkemize kitlesel olarak göç etmişlerdir. Suriye sınırında yer alan illerimizde geçici barınma merkezleri kurulmuş ancak zaman içerisinde göçmen sayısının fazla olması ve geçici barınma merkezlerinin sınırlı kapasitede olması nedeniyle Suriyeli mülteciler kamplara yerleşmeden şehirler veya kırsal alanlara yerleşmişlerdir. Suriyeli mültecilerin yoğun olarak yaşadığı illerden biri de Şanlıurfa olmuştur. Özellikle sınırda yer alan Akçakale, Ceylanpınar ve Suruç mültecilerin geçiş yeri olarak kullandıkları ilçeler olmuştur.

Şanlıurfa ilinde eğitim gören Suriyeli öğrencilerin ilçe ve mahallelere göre dağılışları Suriyeli mültecilerin il içerisindeki dağılışları hakkında fikir sahibi olmamızı sağlamıştır. Buna göre; Akçakale, Ceylanpınar ve Suruç ilçeleri sınırda yer aldığından, Haliliye ve Eyyübiye ilçeleri de iş imkânlarının olması, şehre has hayat tarzı ve olanakların daha fazla olması nedeniyle mültecilerin daha fazla dağılış gösterdikleri ilçelerdir. Birecik ve Viranşehir ilçelerinde Suriyeli mülteci sayısı Bozova, Halfeti, Hilvan ve Siverek ilçelerine göre tarihi İpek Yolu üzerinde yer aldıklarından daha fazladır. Sosyo-ekonomik olarak fazla gelişim göstermemiş olan Bozova, Hilvan ve Halfeti Suriyeli mültecilerin en az dağılış gösterdikleri ilçelerdir. Karaköprü ilçesinde dağılışın az olması konut kiralarının yüksek olmasından kaynaklanmıştır.
Suriyeli mültecilerin mahallelere dağılışı sosyo-ekonomik yapıya bağlı olarak şekillenmiştir. Kırsal mahallelerde dağılış az iken şehirlerde merkezi iş alanlarının olduğu semtler ve kira fiyatlarının düşük olduğu mahalleler tercih edilmiştir. Mülteci dağılışının en fazla olduğu Haliliye ve Eyyübiye ilçelerinde; Devteşti, Bağlarbaşı, Süleymaniye, Ahmet Yesevi, Cengiz Topel, Bamyasuyu, Şehitlik, Yeşil Direk, İmam Bakır, Şair Nabi, Sancaktar, Hayatı Harrani, Eyüpkent, Direkli, Akşemsettin, Eyyüpnebi, Muradiye, Akabe, Topdağı, Haleplibahçe, Kurtuluş, Onikiler ve Hakimdede mültecilerin en fazla dağılış gösterdiği mahallelerdir. Bu mahallelerin bir kısmı Şanlıurfa şehrinin nüvesini oluşturmakla beraber bir kısmı da kırsal alanlardan yapılan göçlerle gecekondulaşmanın olduğu geliri düşük olan insanların yaşadığı mahallelerdir. Bu nedenle ekonomik olarak zorluk çeken Suriyeliler bu mahallelerde daha fazla dağıllış göstermektedir.

Suriyeli mültecilerle yapılan mülakatların analizi yapılarak bazı sonuçlara ulaşılmıştır: Mültecilerin göç süreçleri sosyal ağlar kullanılarak yapıldığından sınırdan geçişler kolayca yapılmış ve Suriyeliler hızlı bir şekilde topluma adapte olmaya çalışmışlardır. Yerel halkla uyumu zorlaştıran en önemli sorun dildir. Bunun dışında işsizlik ve ekonomik sıkıntılar, 100-120 m² evlerde geniş aile bireylerinin beraber kalması, 2017 yılından sonra ülkemizde ekonomik durgunluğun yaşanması nedeniyle sorumlu olarak Suriyelilerin görülmesi yine bu tarihten sonra insanların Suriyeli mültecileri dışlamaları da mültecilerin entegrasyonunu zorlaştırmıştır.

Suriyeli mültecilerin iş merkezlerinde kendilerine ait işyerleri açmaları birçok ilde olduğu gibi Şanlıurfa'da da arz talep açısından olumlu sonuçları olmuş olsa da yerel halk içerisinde işsiz sayısı arttığından ucuz işgücü olarak görülen Suriyelilere karşı münferit veya kitlesel tepkiler gösterilmektedir. Suriyeli mültecilerin gerek sosyal ve gerekse de mekânsal kümelenmeler oluşturmuş olmaları kendi kimlik ve kültürlerini yaşamaları konusunda olumlu sonuçları olsa da aidiyet duygusunun yerleşmesi ve uyum konusunda sorunlar oluşturabilmektedir. Nitekim 2017 y1lından sonra komşuluk ilişkilerinin zayıfladığ ${ }_{1}$ ve dışlanma olgusunun arttığı anlaşılmıştır. Bunun dişında sağlık ve eğitim hizmetlerinin Suriyeli mültecilere ücretsiz verilmesi de yerel halk arasında tepkilere yol açmaktadır.

Suriyeli kadın mültecilerin uyumunu zorlaştıran hususlardan biri yerel halk arasında kız çocukları veya kadınlara olan bakış açısıdır. Suriyeli kadınların parayla alınıp satılabilecek bir eşya olarak görülmeleri, kuma olarak alınmaları, yaşlı insanlarla para 
karşılığında evlendirilmeleri özellikle kadın mültecilerin uyumunu zorlaştırmaktadır.

Sonuç olarak; Suriyeli mülteciler ülkemizin önemli sorunlarından biri olmaya başlamıştır. Yerel halk tarafindan Suriyelilere karşı bir takım dışlayıcı davranışlar olsa da katılımcıların büyük bir kısmı güvenlik nedeniyle Suriye’ye dönmeyi düşünmemektedir.

\section{KAYNAKLAR}

Bartram, D., Poros, M. V., \& Monforte, P. (2017). Göç Meselesinde Temel Kavramlar. (I. Ağabeyoğlu Tuncay, Çev.) Ankara: Hece Yayınları.

Boyd, M. (1989). Family and Personal Networks in International Migration: Recent Developments and New Agendas. International Migration Review, 23(3), 638-670. https://doi.org/10.1177/ 019791838902300313

Castles, S., Haas, H. \& Miller, M. (2014). The Age of Migration. New York: Palgrave Macmillan.

Çakır, S. (2011). Geleneksel Türk Kültüründe Göç ve Toplumsal Değişme. Süleyman Demirel Üniversitesi Sosyal Bilimler Dergisi, 24, 129-142.

Epstein, G. S. (2008). Herd And Network Effects In Migration DecisionMaking. Journal of Ethnic and Migration Studies, 34(4), 567-583. https://doi.org/10.1080/13691830801961597

Harunoğulları, M. (2016). Suriyeli Sığınmacıların Kilis Şehrindeki Mekansal, Kültürel ve Ekonomik Etkileri. The Journel of International Social Research, 9(45), 373-395.
Karpat, K. H. (2013). Osmanlı'dan Günümüze Etnik Yapılanma ve Göçler. (B. Tırnakçı, Çev.) İstanbul: Timaş Yayınları.

Keleş, R. (1998). Kentbilim Terimleri Sözlüğü. Ankara: İmge Kitabevi. Lee, E. (1966). A Theory of Migration. Demography, 3(1), 47-57. https://doi.org/10.2307/2060063

Massey, D., Arango, J., Hugo, G., Kouaouci, A., Pellegrino, A., \& Taylor, J. (1993). Theories of international migration: A review and appraisal. Population and Development Review, 19(3), 431-466.

Munshi, K. (2003). Networks In The Modern Economy: Mexican Migrants In The U.S. Labor Market. The Quarterly Journal of Economics, 118(2), 549-599. https://doi.org/10.1162/003355303321 675455

Özer, İ. (2004). Kentleşme, Kentlileşme ve Kentsel Değişme. Bursa: Ekim Kitabevi.

Proshanksy, H. M. (1978). The city and self identity. Environment and Behavior(10), 147-170. https://doi.org/10.1177/0013916578102002

Sertkaya Doğan, Ö. (2009). Nüfus Coğrafyası Açısından Bir İnceleme: Silivri. Marmara Coğrafya Dergisi(20), 1-19.

Tanoğlu, A. (1969). Nüfus ve Yerleşme. İstanbul: Taş Matbaası.

Tümertekin, E. \& Özgüç, N. (2002). BEŞERI COĞRAFYA İnsan, Kültür, Mekan. İstanbul: Çantay Kitabevi.

Tümtaş, M. S. (2009). Yoksulluktan Yoksunluğa Göç: Marmaris ve Mersin Örnekleri. Toplum ve Demokrasi Dergisi, 3(5), 111-134.

Uysal, A. (2015). Londra'daki Türklerde Aidiyet ve Mekan İlişkisi. Ístanbul Üniversitesi Edebiyat Fakültesi Coğrafya Bölümü Coğrafya Dergisi(30), 61-78.

Zapata-Barrero, R. \& Yalaz, E. (2018). Introduction: Preparing The Way For Qualitative Research in Migration Stıdies. R. ZapataBarero, \& E. Yalaz içinde, Qualitative Research in European Migration Studies (s. 1-31). Barcelona-Catalonia, Spain: Springer. 